\title{
Salendang Dance Galombang Version as a Welcome Dance in the Mandeh Tourism Area
}

\author{
$\operatorname{Nerosti}^{1, *}$ \\ ${ }^{I}$ Sendratasik Department, Faculty of Language and Art, Universitas Negeri Padang, Padang, Indonesia \\ *Corresponding author. Email: nerosti@fbs.unp.ac.id
}

\begin{abstract}
This article is the result of research (2021) which aims to develop the choreography of the Salendang Dance in the form of Galombang to be performed in the Mandeh tourist area. The method used by Research \& Development (R\&D) according to Borg and Gall (2003) is to conduct preliminary research, planning, development to be carried out, testing, revising works and perfecting choreography. The development of choreography refers to Maquet's theory (1976) naming the form of tourism packaging as art with metamorphosis or art that has undergone a change in form, or acculturation art, or pseudo traditional art, or tourism art. Art that has not been packaged is called art by destination. The Wimsatt diagram (Soedarsono 1999) states that tourism performances are a balance between traditional arts and the tourism industry, with the following criteria: imitation of the original, short and concise, full of variations from the original event, and if sold at a low price. Based on the results of the first year's research, it produced Salendang Dance products in the form of performances on stage. The second year produced the Salendang Dance in the form of a Galombang. This dance has been tested in Muaro Bantieng, Mandeh Region. 10 dancers and 3 people who carry betel nut danced using a scarf in a two-line formation lining the back. Continue forward to meet the tourists who stand in front of them. The dance package includes various aspects of movement, music, costumes, and make-up in accordance with the aesthetic concept of tourism, which still refers to the original dance form as a symbol of the Puti-puti Tarusan lineage. This new style is worth showing off to tourists.
\end{abstract}

Keywords: Salendang dance Galombang version, tourism performing arts, choreography and Puti- puti's descent

\section{INTRODUCTION}

This article is the result of the second year of research entitled "Development of the Salendang Dance Choreography with the Concept of Tourism Performance in the Mandeh Region", which ran for two years. The first year (2020) has produced a product, namely the Salendang Dance which is packaged in the form of a performance on a stage that has been published with the title article: "Salendang Dance Choreography Developing The Arts Of Tourism Performance In Mandeh". Tahun kedua (2021), produces a product, namely the Salendang Dance which is packaged in the form of a Galombang or a welcoming dance that is served in front of tourists in Muaro Bantieng, Mandeh Region. Both dances are reconstructions of the Salendang dance from the descendants of Puti-puti Tarusan. which is almost extinct and is now worth showing to tourists around Mandeh.

The choreography of the Salendang Dance, which used to be to welcome the king's child to marry, is now arranged in a new form in the art of tourism performance, in addition to commercial or professional purposes as well as to maintain traditional dances in the District of Koto XI Tarusan. The development of performing arts in a country never escapes the economic growth in that country. If economic growth is good, it means that some of the average income per capita of the population can be set aside for recreation, then the development of commercial performing arts will also be good (Nerosti, 2020).

This research begins with the reconstruction of the Dampieng Salendang Dance. Dampieng in the form of vocals by singing Ayoo Dampieng. Come on, come on. When the accompaniment is sung, the women play with their shawls, stretching them out, waving the shawls, rolling them like ropes to tie them all to the groom of the descendants of King Tarusan who came with his entourage to the bride's house to carry out the marriage ceremony. The dismembered movements are what the researcher arranged into motion phrases into seven types of movements, 
namely warih, paga, anta, balabeh, limpapeh, ikek, kuriek kundi, and Anjuang (Nerosti, 2020)

Salendang dance is one of the traditional dances that has developed since the Tarusan kingdom which joined the autonomous nagari federation was still victorious (Mansoer, 1970: 79). With the handover of the autonomous nagari federation to the 17th century company witnessed by Sri Sultan Achmad Sjah Jang Dipertuan in Minangkabau for the sake of politics and smooth trade (Mansoer, 1970: 101), over time the power of the small kingdoms was decreasing. Even so, the Tarusan Kingdom survived to 9 generations. Listening to this history, the Salendang Dance, which once developed among the Puti-puti descendants of King Tarusan, needs to be reconstructed. Reconstruction has been carried out in previous research (2018),

This research is synchronized with a government program that is currently orbiting the Mandeh Integrated Area as a Tourist Destination. Since November 25, 2017, Mandeh has won the first place in the Most Popular Hidden Paradise category with the Pesona Indonesia (API) II award for Marine Tourism (www.jurnalsumbar.com〉PARIWARA). Various marine tourism activities are held and even the Mandeh Festival which also organizes various traditional arts from each nagari has also been scheduled once in 2 years. The development of Mandeh tourism is like a gold field for the community, especially if it is supported by infrastructure facilities with the construction of a pass from Bungus Teluk Kabung Padang to the Mandeh area. This situation also has a positive impact on the life of traditional arts around the Mandeh area. Although many traditional arts have become extinct, due to the expertise of the tourism industry, performing arts that are almost extinct can be revived (Soedarsono, 1999: 3) referred to as art by metamorphosis or art that has undergone a change in form, or art of acculturation or the art of acculturation. namely pseudo traditional art, known as tourist art or tourist art. Art that has not been packaged is referred to as art by destination, which is art used by the people themselves. Soedarsonoindustry, performing arts that are almost extinct can be revived (Soedarsono, 1999: 8). Tourist performing arts that need to be short, concise, and interesting and for packaging performing arts for tourism purposes J. Maquet (1976) is referred to as art by metamorphosis or art that has undergone a change in form, or art of acculturation or the art of acculturation. namely pseudo traditional art, known as tourist art or tourist art. Art that has not been packaged is referred to as art by destination, which is art used by the people themselves. Soedarsono (1999:13) uses the
Wimsatt diagram of a group of immigrant communities, namely the tourists presenting a certain art style, at the same time the local community will maintain traditional art. The art performed in the tourism industry is a blend of tradition and tourism. industry, performing arts that are almost extinct can be revived (Soedarsono, 1999: referred to as art by metamorphosis or art that has undergone a change in form, or art of acculturation or the art of acculturation. namely pseudo traditional art, known as tourist art or tourist art. Art that has not been packaged is referred to as art by destination, which is art used by the people themselves. Soedarsono (1999:13) uses the Wimsatt diagram of a group of immigrant communities, namely the tourists presenting a certain art style, at the same time the local community will maintain traditional art.

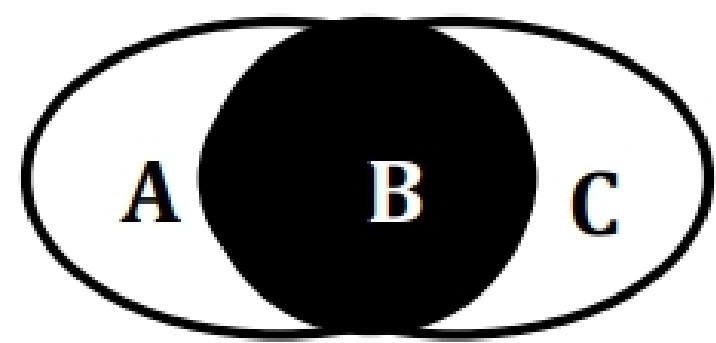
A. Traditional Performance
B. Tour Show
C. Tourisme Industry

The art performed in the tourism industry is a blend of tradition and tourism. infrastructure facilities with the construction of a pass from Bungus Teluk Kabung Padang to the Mandeh area. This situation also has a positive impact on the life of traditional arts around the Mandeh area. Although many traditional arts have become extinct, due to the expertise of the tourism industry, performing arts that are almost extinct can be revived (Soedarsono, 1999: 3).

\section{METHOD}

Metode penelitian yang digunakan adalah Research \& Development (R\&D) yang dikembangkan oleh Borg dan Gall (1989) dengan 10 langkah kerja penelitian: (1). Research and Information colletion (melakukan penelitian pendahuluan), yang telah peneliti lakukan pada tahun (2). Planning (melakukan perencanaan), (3) Develop Preliminary form of Product (mengembangkan produk awal), (4) Preliminary Field Testing (iji coba lapangan tahap awal), (5) Main Product Revision (Melakukan revisi produk operasional), (6) Main Field Testing (uji coba lapangan utama). (7) Operational Product Revision 
(melakukan revisi 8). Tourist performing arts that need to be short, concise, and (8) Operational Field Testing (uji coba lapangan operasional), (9) Final Product, (10) Disemination and Implementasian (deploy and apply) interesting and for packaging performing arts for tourism purposes J. Maquet (1976) is produk operasional.

\section{RESULTS AND DISCUSSION}

The Salendang dance originally developed among the women of Tarusan Kingdom descent in the XVIII century, which was danced by women only to welcome the Son of the King or the title of Sutan before being side by side on the aisle. The origin of Puti-puti's descendants in Tarusan can be heard from Ranji at Princess Noermaya's house, which started from (1) King Tarusan named Sutan Djahja who was entitled Sutan Perhimpunan Alam. At first he became the Penghulu Chief in Nagari Sungai Pinang. On March 23, 1876, he was appointed Head of the Laras in Tarusan. Swear at Painan. Stop with a request for a pension. On 19 January 1912, he was awarded the One Silver Star. Here on June 1, 1881 to 1951. (2) King Tarusan St. Kadir Pourku Radja Hitam. At first the kingdom sat in the hamlet then moved to the Talang River. At that time the Company came to Malaboh to die because of Tuak. Then the Radja returned to the hamlet and died buried in Mandah Hill. (3) Radja Tarusan St. Satih Titled Radjo Hitam Pourku Nan Goreng. Prayed with the Company in Padang. Sitting royally in Pondok from 1708 to 1722 . This is when Radja Sungai Pinang died and was buried in Bukit Mandah. (4) Radja Tarusan, the name of St. Dajat, the title of Bagindo St. Besar, reigned in Nanggalo from 1738 to 1756 . He married a woman Setia Wanara Salido, brought by Ninik to Nanggalo Tarusan. The king died and was buried in Bairah Limau Puruik in Nanggalo. Then in 1956 he was transferred (Dokar) near the site from 1776-1796. (8) King Tarusan Sutan Madat gave the title Tuanku Rajo Hasan. Sweared with the Padang Company on March 28, 1724 to November 26, 1854. He built a long house in Nanggalo Tarusan. In 1954 JC Eigger came to Tarusan to be buried opposite the Pondok. He moved to be buried there. (9) King Tarusan St. Ismael, the title of Bagindo St. Besar, began with the King of Sungai Pinang on January 9, 1855, taking an oath with the Company in Padang Regent. Quit by request on February 18, 1876, then died.

From the Ranji obtained from Princess Noermaya, it is proven that in Tarusan there are indeed descendants of Princess Raja, also known as the descendants of Puti-puti, which we can now meet in Tarusan, namely Princess Reno Intan and Princess
Noermaya. Therefore, the existence of the Selendang dance in Tarusan is true, it is one of the traditional dances that should be preserved.

In the process of developing the choreography of the Galombang version of the Salendang Dance, the form of the Galombang dance that is widely developed in Minangkabau is unique, but this dance is unique in using the property of salendang.

Galombang dance is a traditional Minangkabau dance which is always presented as a dance to welcome guests in various Minangkabau traditional ceremonies, such as the coronation of the Penghulu (tribal head), weddings, bathing, and alek nagari. Initially danced by dozens of men in a martial arts style, also known as silek galombang. In its development, the Galombang Dance was dominantly danced by women with various creativity so that it gave rise to a new choreography, both from the aspect of dancers, motion, floor patterns, music, property, and costumes and make-up, but still displaying the aesthetic symbols of Minangkabau customs (Nerosti, 2013). Because Minangkabau has made the Galombang Dance as a welcome guest, the Salendang dance is arranged in the form of a Galombang, with a formation of 10 dancers and three carano carriers. The shape of the Salendang Dance still refers to the original Salendang dance motif, but has been created in terms of motion, floor patterns, costumes and music. For more details, the composition of the movement of the Galombang version of the Salendang Dance is arranged as follows:

(1)Warih, this movement starts the Galombang Dance, all the dancers put a scarf in both hands and slowly walk towards the guests/tourists. This movement is likened to the saying "Warih samo dijawek, pusako samo is helped". This means that inheritance becomes a moral responsibility for the lineage that receives it to pass on to the next generation. Heirlooms must be equally helped to maintain it. The legacy will continue to be passed down to the next generation.

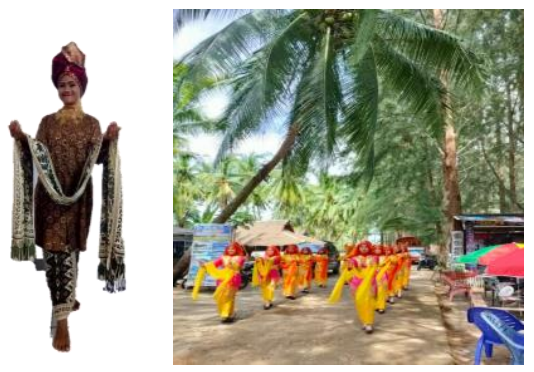

Figure 1 Warih movemnet 
2). Paga. This movement can be interpreted as "Kuek nan dari paga basi, kokoh nan dari paga tembok" meaning that the strongest fence is the fence of something with good character. This movement is done in place, sometimes forward and sometimes backward.

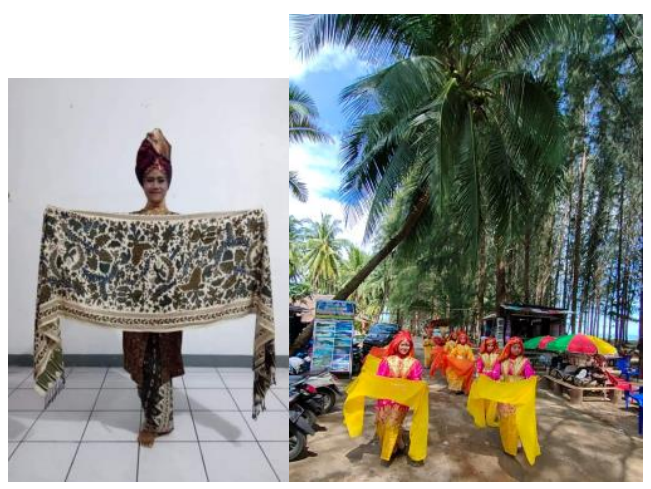

Figure 2 Paga movement

3) Anta, this movement is the opening movement of the Salendang dance, which is performed at the beginning of the dance when the groom has arrived at the bride's house to carry out the marriage contract. The anta movement serves to take the groom to the aisle, but in the dance performance when the groom arrives at the yard of the bride's house, dampiang is immediately sung. There are 8 dancers in total

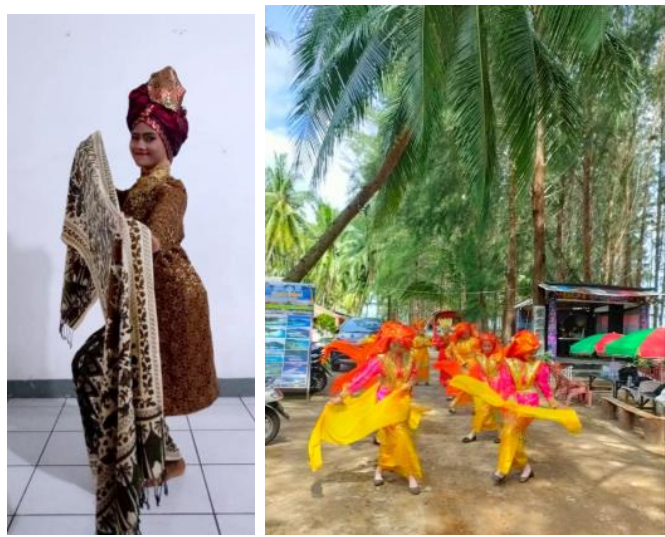

Figure 3 Anta Movement

4). Balabeh is firmness in maintaining inheritance, both in the form of heirlooms and in the form of nonphysical, namely customs that must always be maintained. "Barih balabeh nan ko kini, nan warih bajawek juo, kaganti gujalo tubuah, paukua bayangbayang maso" This means that if the traditional teachings are explored, they will be able to become a measure of the progress of the times in the field of human morals. Therefore, in this motion, the scarf is always firmly stretched. This movement is done while walking, in a diagonal direction to the right and to the left. Every step that is taken always uses a double step or step to give birth. So that the movement is effective up and down.

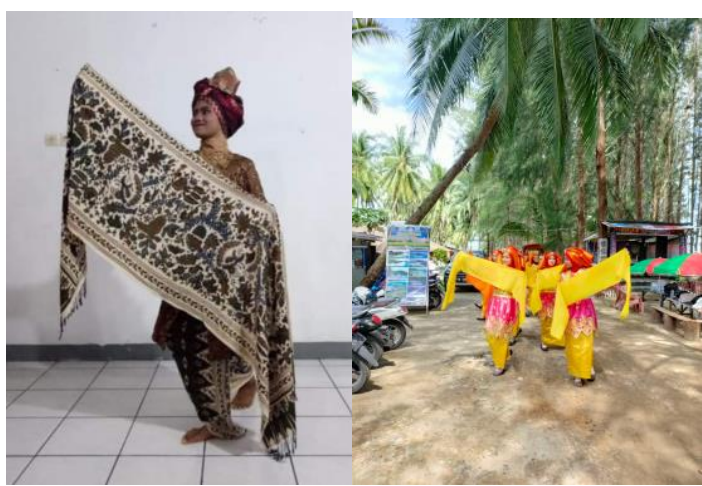

Figure 4 Balabeh movement

5) Limpapeh, this motion imitates a flying butterfly. This can be interpreted based on the Minangkabau petitih adage: Limpapeh rumah nan gadang, umbun puruak holding the key. Women in Minangkabau are solid pillars on the household and country, and the key to the good and bad of a country. This movement aimed at women is interpreted as advice for the bride. Lympapeh which is a small fragile white butterfly. The wings are very easily damaged even if exposed to the wind the wings can be torn. Therefore, it is westernized to women who must be good at taking care of themselves. The subtlety of language outwardly should be accompanied by a gentle mind, because women are housewives who will educate children as descendants of kings and princesses. Women also have to be trustworthy because they are the holders of inheritance in the rumah gadang.

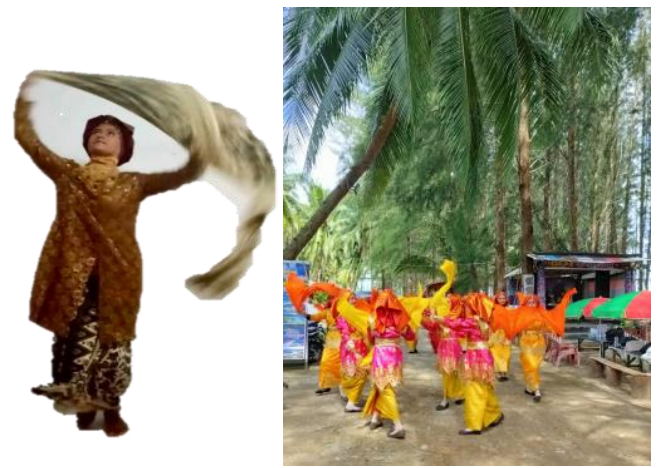

Figure 5 Limpapeh movement

6). Ikek This gesture is interpreted as the wife's duty to bind her husband's heart, through good service. All the 
needs of the husband can be met by the wife. It is expressed in the proverb: "Padi diikek jo daunnyo, batang ditungkek jo dahannyo". The wisdom that is used by someone in leading a nephew's son, to finance it, is looking for an effort.

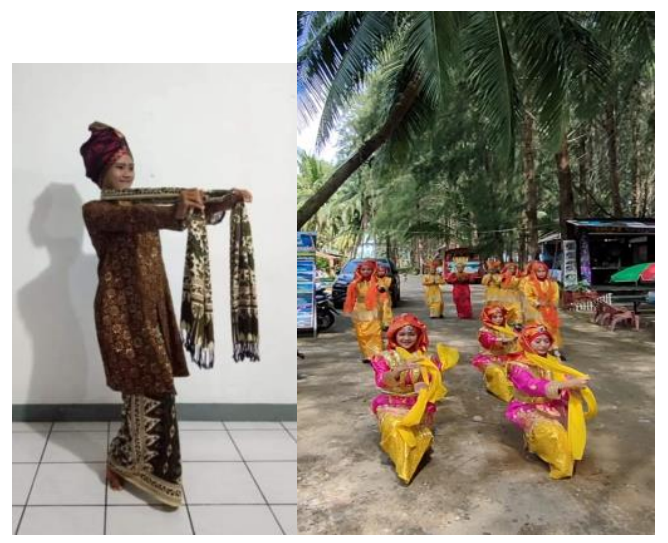

Figure 6 Ikek movement

7). Kuriek Kundi: Nan kuriek iyolah kundi, nan merah iyolah sago, nan baiek iyolah budi,nan endah iyolah baso. The most valuable meaning in social life is to associate with good character and manners

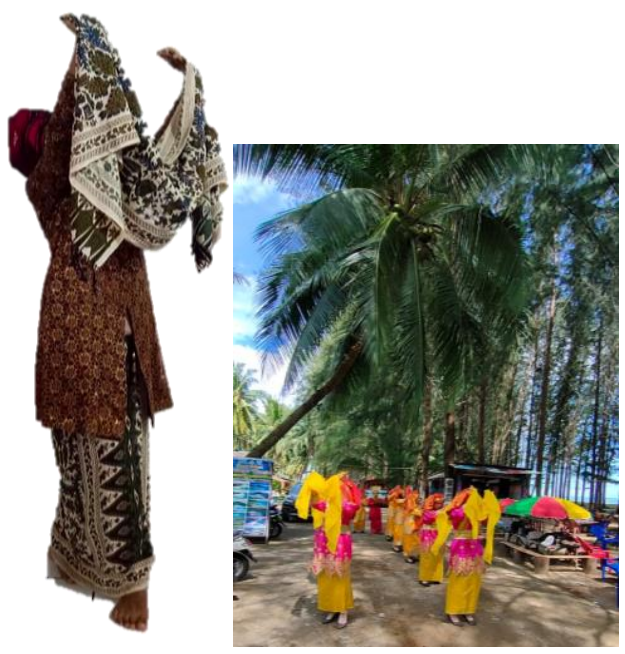

Figure 7 Kuriek Kundi movement

In society, measuring identity can be monitored through three forms, namely cultural identity, social identity, and personal identity (Liliweri, 2002). Cultural identity arises because a person is a member of a certain ethnic group, one of which is by always identifying the Minang people as Muslims, while social identity is the result of membership in a cultural group.

Therefore, at first, traditional dance offerings were closely related to religious activities and customs. By understanding that traditional dance is full of traditional values, it has functioned for educational purposes which are taught for special purposes in education (Kraus, 1969:4, Rina, 2012:21).

It is very different from the current conditions, in the royal era where performing arts functioned as a complement to the splendor of the palace, magnificent performances were held at the palace with production funds borne by the king (Soedarsono, 2010: 105).

Nerosti (2019) Although not all kingdoms in Indonesia in ancient times were large kingdoms that performed performing arts, even small kingdoms had performance arts including dance performed at certain events within the kingdom. Along with the dissolution of the kingdom in Indonesia, the performing arts that developed within the kingdom automatically also did not succeed anymore, except in Java, there are still some royal remains that are well preserved, while in many small kingdoms that have become extinct, melting into art that belongs to people. (Although not all kingdoms in Indonesia in ancient times were big kingdoms that held performing arts, but even small kingdoms had performing arts including dance that was held at certain events within the kingdom. Along with the dissolution of the kingdoms in Indonesia, the arts Performances that developed within the kingdom automatically also failed, except in Java. There are still royal heritages that are well preserved, while in the small kingdoms many have become extinct, merging into art that belongs to the people).

\section{CONCLUSIONS}

The development of Salendang Dance has produced a dance product that is ready to be displayed to tourists in the Mandeh area. The development of choreography occurs not only because of the preservation factor, but also because of the professional factor which is characterized by creativity. Satisfying tourists is a job that must be done, in order to improve the lives of artists, orders are always coming, the motivation is money. Money is not just a symbolic expression of aspects of life, but money is also a symbolic expression of other aspects of life such as social, cultural, political, and religious (Damsar: Sociology of Money, 2006: 34). The change that marks the present era is marked by the change of the male icon to the female icon. 


\section{REFERENCES}

1. Gall, Meredith D.Gall Joyce P. \& Borg,Walter R. (2003). Educational ResearchAn Introduction, Seventh Edition. Boston: Pearson Education Inc.

2. Grabburn, Nelson HH, (1976). Etnic and Tourist Arts, New York City.SEp?

3. Handayaningrum, Warih and Wulan, Puspitaning. Pesona Tari sebagai Aset Pariwisata Budaya Indonesia. SALAM; Jurnal Sosial \& Budaya SyarI FSH UIN Syarif Hidayatullah Jakarta, Vol. 7 No. 4 (2020), pp. 283-298, DOI: 10.15408/sjsbs.v7i4.14925

4. Holt, Claire. (1967). Arts Indonesia: Countinuities and Change. Ithaca: Cornell University Press.

5. Hopkins, Jerry, (1981). The Hula, Hawaii University Press.

6. Indra Utama. (2017). Tari Minangkabau: Dari Pancak dan Pamenan ke Tari Persembahan. Kuala Lumpur: Penerbit Universiti Malaya.

7. Kraus, Richard. (1969) History Of The Dance In Art And Education. New Jersey: Prentice-Hall.

8. Liliweri. (2002). Makna Komunikasi Dalam Komunikasi Antar Budaya. Yogyakarta: LKiS.

9. Mansoer. (1970). Sejarah Minangkabau. Djakarta: Bhatara

10. Maquet, J. (1971). Introduction to Aesthetic Anthropology. Massachusetts: Addison Wesley.

11. Melany. Tari Topeng Malangan Sebagai Alternatif Wisata Budaya Di Kota Malang. Jurnal Ilmiah Hospitality dan Pariwisata. Vol 1 (2015).P.43-61

12. Nerosti (2013) "Tari Galombang di Minangkabau Menuju Industri Pariwisata". Journal of Urban
Society's Art, Vol 13, No 2, Oktober 2013. pp. 110-118.

13. Nerosti. (2017a). Tiga Gaya Tari Rantak Kudo Berpotensi Sebagai Sajian Pariwisata di Kawasan Mandeh dan Sekitarnya. Jurnal of Urban Society's. Vol 4, No 2-Oktober:89-102.

14. Nerosti. (2019a). "Nilai-Nilai Kearifan Lokal Melalui Tari Galombang Gaya Sasaran: Studi Sasaran Sebagai Sarana Pendidikan Kultural". Jurnal Dance \& Theatre Review. Volume. 2 Number 1. May 2019. P. 35-41.

15. Nerosti (2019b). "Dampieng Salendang Reconstruction in Building Millenial Generation Characters in the Field of Dance" Proceedings of the International Conference On Social Studies, Globalisation And Technology (ICSSGT 2019). Atlantis Press. Advances in Social Science, Education and Humanities Research, volume 458. P. 430-439.

16. Rina Martiara. (2012). Nilai Dan Norma Budaya Lampung Dalam Sudut Pandang Strukturalisme. Yogyakarta: Institut Seni Indonesia Yogyakarta. Program Pascasarjana

17. Soedarsono, R.M. (1999). Seni Pertunjukan Indonesia dan Pariwisata. Jakarta: MSPI.

18. Surheni. (2015). "Empat Koreografer Minangkabau: Dibaca dalam Teks Matrilineal dan Patrilineal" Jurnal of Urban Society's, Vol. 2 No. 2, Oktober 2015, 63-79.

19. Tommars, Adolph S. (1964). Class System and the Arts, in Werner J. Cahnman, and Avin Boskoff, eds. Sociology and History Theory Reasearch. London: The Free Press of Glence. 